Scientific Bulletin, № 2, 2021, pages 26-31

Natavan Abdulla Kamilova, kamilova.natavan@mail.ru

Western Caspian University

DOI: doi.org/10.54414/niyi4983

e-ISSN: $2789-4614$

\title{
LINGUISTIC FEATURES OF THE NOVEL "ALI AND NINO"
}

\section{ABSTRACT}

This paper studied the novel G. Said in the use of linguistic resourcesand identify their functional characteristics. Revealed that in the novel «Ali and Nino» occurring most expressive means are epithets. The second highest number of use metaphor. In third place phraseology, also justified the use of the means of expression in the works.

Keywords: figurative and expressive means, epithets, metaphors, phraseology, stylistic figures

\section{"QURBAN SOIDİN “ӘLİ VO NINO” ROMANINDA DILL VASITOLORI}

\section{XÜLASə}

Maqabdə Q. Səidin romanı dil vasitəbrindən istifadə vo onları funksional xüsusiyyətbrini müəyyənlaşdirmok baxımindan araşdırlir. Müəyyənbşdirilmişdir ki, "Oli və Nino" romanında ən çox rast gəlimøn ifadə vasitəlbri epitetbrdir. İstifadə baxımmdan ikinci yerdə metafora, üçüncü yerdə frazeologiya dayanır. Osərlərdə bu ifadə vasitəbrindən yerində istifadə olunmuşdur.

Açar sözlor: vizual və ifadəli vasitəbr, epitetbr, metafora, frazeologiya, stilistik raqəmbr.

\section{ЯЗЫКОВЫЕ ОСОБЕННОСТИ В РОМАНЕ КУРБАНА САИДА «АЛИ И НИНО»}

\section{РЕЗЮМЕ}

В статье исследован роман К. Саида с точки зрения использования языковых средств и выявления их функциональных особенностей. Выявлено, что в романе «Али и Нино» наиболее часто встречающимся средством выразительности являются эпитеты. На втором месте по количеству употребления находятся метафоры. На третьем месте фразеология; также обосновано употребление данного средства выразительности в произведениях.

Ключевые слова: изобразительновыразительные средств, эпитеты, метафоры, фразеология, стилистические фигуры. 
Кавказ - один из прекрасных уголков земного шара, всегда был и остается краем, который манил к себе не только писателей и пугешественников, но и политиков. Кавказ, как его еще и называли «теплой Сибирью», привлекал своей экзотической культурой и традициями. Сказочный, таинственный и загадочный, самобытный и богатый Кавказ всегда манил и привлекал многих пугешественников, ученых и писателей. Экзотическая и удивительно прекрасная природа Кавказа, обычаи и характер кавказского народа составляют основную сюжетную линию произведений многих русских писателей: А.С. Пушкина, М.Ю. Лермонтова, Л. Н. Толстого, С. Есенина, А Ахматовой, Б. Пастернака и многих других.

Не учитывая вольнолюбивый и гордый дух кавказцев, упорно направляя свои усилия на захват земель, еще в начале XX века Российская империя начала военные собыпия. Захватническая политика Российской державы вызвала волну протеста и стала началом борьоы кавказцев за свое освобождение.

Тема русско-кавказской войны становится одной из главной темой, которая исследуется и анализируется не только в русской, но и в национальных литературах. Роман «Али и Нино», исследуемый нами, был написан писателем-эмигрантом М. Асад беком, взявшим себе псевдоним Курбан Саид и издан в 1935-ом году в Вене на немецком языке и переведен на 33 языка.

Это роман об экзотической восточной стране и запретной страсти, о грандиозных исторических событиях, происходящих в начале XX века.В центре романа, с одной стороны, любовь молодого хана Али Ширван- шира мусульманина строгих правил и грузинской княжны Нино Кипиани - свободолюбивой и европеизированной христианки.

C другой стороны- начало XX века - Баку накануне большевистской революции. Нефтяной бум, война, революция, борьба Азербайджана за независимость.

Роман двух влюбленных - это роман о противостоянии мусульманской и христианской, европейской и азиатской культур на примере отдельно взятой пары. Это трогательная романтическая история, действие которой разворачивается на фоне драматических событий первой четверти прошлого века. Как нам известно, восточные истории о любви имеют печальный конец, но мы их любим за неповторимый колорит, самобытность, интересное описание жизни, культуры и обычаев. События, изображенные в романе и передаваемые от лица его героя Али хана, охватывают значительные моменты истории Закавказья и Азербайджана: революцию и первую мировую войну, образование Азербайджанской Демократической Республики и ее падение, захват болышевиками Гянджи и Баку.

Особенности романа дают возможность говорить об исключительно экспрессивном характере его стилистики и поэтики в целом. Написанный лаконичным языком, так сказать «емким слогом», в котором остается место для «соучастия», текст романа полон неожиданных коллизий, действие в нем порой неожиданно и стремительно меняется, так же как

«декорации〉 и 〈место» действия, причем они зрелищны и многообразны: это и особняки аристократов, площади и улицы городов, волны Каспия, схватки, погони, бальные 
сцены, окопы и классы пимназии.

Язык романа «Али и Нино» необычайно богат и разнообразен. Автор в языковом материале романа прежде всего стремится к естественности языка и форм. Художественная речь писателя отражает сложный, глубинный анализ изображаемой жизни. Писатель стремился показать читателю не результат своих наблюдений, а сам поиск истины. Читая роман, мы видим, как автору важно показать пугь героя, борьбу в его душе, умело отражая «диалектику его души».

Среди языковых средств в романе автор широко использует: эпитеты, сравнения, метафоры, пословицы и поговорки, фразеологизмы, антитеза, тюркизмы, грузинская лексика, гипербола, лексический повтор, аллитерация, с помощью которых вскрывает естественную сущность явления. ЭПИТЕТЬ: «Небо низвергало на нас потоки пламени (с.16); врата печали, открывающие пугь к небесам (с. 228); море факелов (с. 229); стройные тела кипарисов (с.197); шелудивая собака (163); желтые лица дынь (145); надменные и суровые словно древние боги, скалы бросали тень на эту иссохшую землю (с. 194); голубым туманом (с. 129); магический лев (с.17); маслянистые черные глаза (c.111); золотые кокарды (c.12); целебный взгляд (c.17); ясный и византийский взгляд (с. 27); жадные глотки (с. 61); греховный концерт (с. 142). СРАВНЕНИЯ: «портрет напоминает византийские иконы (с.27); люблю гудящую тыму ночи (с. 26); подобно вырвавшимся на волю арестантам, бросились вниз по лестнице (с. 31); евнух дяди с лицом, напоминающим высохшую кожицу ящерицы (с. 37); твой стан, как персидская сабля (с. 43); твои губы - пылаюший рубин (с. 42); красавица моя, как мышь, крадешься ночь в соседний дом (с. 42); ножки у нее были маленькие, как у куколки (с. 45); хищной птицей кругил, Илья соколом преследовал стремительно (с.45); будто сплетенного из бесчисленного количества нитей и напоминающегодевичью косу (с. 46); степь проста, как удар мечом. Лес же- это запуганный гордиев узел (с.56); дом напоминает муравейник. Небо неподвижно висело над городом. Легкие облачка издали глядели на землю безучастными свидетелями (с. 67); лысины в зале сверкают, как звезды на ночном небосклоне. Яркие цветы делали коврик похожим на неболышую лужайку, которую можно свернупь и захватить с собой в пугешествие (с. 76); неподвижная, будпо лицо покойника, луна (с.143); город накануне сражения казался строгим, хмурым (с. 182); старинный минарет был похож на токую красивую чинару; Персия напоминает протянугую за милостыней руку старого нищего; Персия жила, подобно улитке, укрывшись в раковине своего благоденствия (с. 221); виноград созрел как глаза буйволов (с. 258); из темноты выполз похожий на зловещее чудовище поезд (с. 263); члены комиссии напоминали диковинных зверей (с. 28) и т.д.

МЕТАФОРЫ: «Звериная тоска (с. 76); Губернаторский сад был очень болышим, Дорожки там покрыты асфальтом, по краям их печально склоняют ивы. (с. 33); стоящему на пороге взрослой жизни (с. 33) и т.д.

ПОСЛОВИЦЫ и ПОГОВОРКИ: «У женщины ума, как у курицы перья (с.17); Прежде, чем поручить верблюда покровительству Аллаха, покрепче привяжи его ограде (с. 28); Славная смерть лучше бесславной жизни (с. 78); у палки два конца оба одинаковые (с. 92); узнаешь почем фунт лиха (с. 103); словно гора свалилась с плеч (с. 94); 
око за око, зуб зазуб (с. 25); В голове у них пусто, как в животе голодного осла (с. 94); море и берег, как мужа и жену, объединяет борьба противоположностей (с. 112); не веруй в мертвые камни (с. 130); если гость даже отрежет голову твоему сыну и явится с ней в твой дом, ты должен принять его, накормить и почитать, как гостя (с. 109); Аллах как видишь, приходит напо- мощь своим смиренным рабам (с. 35) и т.д.»

ФРАЗЕОЛОГИЗМЫ: «битых два часа (с. 13); божьей карой (с. 28); стоит ли испытывать судьбу (с. 30); стуча зубами от страха (с. 39); глаза директора вот-вот выскочат из орбит (с. 41); осаждать бастионы запад- ной науки (с. 54); потеряла голову (с. 68); крови будуг литься реками (с. 70); ни единый мускул не дрогнул (с. 19); угрызения совести (с. 13); мир не рухнул бы (с. 21); сущий пустяк (с. 21); закрывать глаза на все (с. 29); судьбу не обманугь, но если и суждено случиться несчастью, то никаким благодеянием его не отвести (с. 38); усиливаются жажды овладеть западные науки (с. 42); пробавляешься объедками с нашего стола (с. 44) и т.д.»

Гипербола: «Кони одним могучим прыжком перелетели через годы (с. 87); дома становятся все ближе и постепенно заслоняли собой и небо, и горы, и город, и царя, и вообще весь мир (с. 34); свинцово-зеленые волны лизали гранитные берега (с. 59); в океане камня (с. 17); суденьшко, прекраснейший, вкуснейший и т.д.»

Хочется сказать несколько слов о переводе. Роман «Али и Нино» - это роман переведенный с немецкого на азербайджанский (это перевод с перевода). Надо отдать должное переводчику Мирзе Гусейнзаде, который оказался прекрасным специалистом не только по точной лингвистической трансляции, но и замечательным мастером слова, сохранивший при переводе особенности оригинала, авторскую манеру, специфику писательского словаря, богатство авторского слова, его стиль, эмоциональность, отпечатки времени культуры. В русской художественной литературе множество интересного примера искусного применения словообразования дпя выражения разнообразного оттенка и эмоциональной окраски слов. Использование выразительных возможностей русского словообразования в романе было обусловлено и особенностью стиля автора, и конкретными художественными задачами. А. Н. Толстой писал: «отбирать точные, меткие, отвечающие смыслу определенного понятия слова

- вот задача истинного писателя» (А. Н. Толстой. Полное собрание сочинений. М., 1989, с.92). Мы знаем, что системы русского склонения, сряжения отличаются редким многообразием и удивительной гибкостью Неограниченным возможностям варьирования обладает.

Глагольная форма. ЕE секрет в том, что в речи одна часть глагольной формы может употребляться вместо другой. Например, при описании прошлых событий глаголы настоящего времени заменяют формы прошедшего времени: «Идет вся та же война, те же генералы одерживают победы или терпят поражения. Вот мы идем на рассвете, встает и веет ветер» (с. 92). Благодаря этому собыпия, о которых повествует автор, словно приближаются к читателю, предстают передним крупным планом: картина разворачивается как бы у нас на глазах. «Глагол- самая огнепьшушая, самая живая часть речи, В глаголе струится самая алая, самая свежая, артериальная кровь языка. Ведь назначение глагола - выражать само действие (А. Югов. «Думы о русском слове.» М., 
1972, с. 89). Русскому глаголу свойственна как бы «надвременность», когда для обозначения настоящего времени одного и того же настоящего времени при- меняется и будущее, и прошедшее и настоящее: «Он любит Нино, но иногда она приводит его в замешательство, изумляет, повергает в сом- нения. Ей доставляет удовольствие, когда на улице на нее заглядывается посторонний мужчина. В то время как восточную женщину это рассердило бы» (141). Обращение писателя к инфинитивным предложениям и употребление глаголов совершенного вида тоже придает повествованию негринужденно - разговорный стиль: «Ну, куда тебе водиться с женой да нянчиться с ребятишками» (с. 78). Благозвучность романа, применение аллитерации, «инструментовка согласных» и « гармония гласных» еще более усиливает эмоционально-экспрессивную окраску: «Гости изобразили на лицах полнейший ужас, Какой-то священнослужитель со ввалившимися щеками, в широкой эммаме тихим, усталым голосом обронил; он обнимал европейскую женщину, е длинные пушистые ресницы щекотали его щеки; он природнял голову, любуясь мягкими чертами лица, полураскрытыми губками, влажными, сверкающими из-под полуопущенных век глазами» (с. 97). Насыщенное использование выразительных средств, стремление к точной выразительности и реалистичномунаполнению изображаемого явления полностью отразили достоинство романа «Али и Нино». Исследование нами лексических, морфологических и синтаксических особенностей этого романа дает возможность говорить об исключительно экспрессивном характере его поэтики и стилистики в целом. Ясность, точность и выразительность фразы, полученные в результате огромной работы, искренность и правдивость тона, богатство лексики и конкретность изложения - вот основные свойства и достоинства языка романа «Али и Нино».

\section{Литература:}

1. С.И.Ожегов «Лексикография. Культура речи», М., 1974

2. Курбан Саид «Али и Нино», издательский дом «Кавказ», 2016.

3. К. Яковлев «О тайнах русского слова», В.-Волжское кн. изд-во, Ярославль, 1999.

4. А. Югов «Думы о русском слове». Изд-во «Современник», М., 2002

5. В. Виноградов «О языке художественной литературы», М., 1959

6. А. Югов «Судьбы родного слова». М., 1992

7. Трудности словоупотребления и вариативность норм литературного языка. М., 1999 